\title{
Impact of Social Support on Life Satisfaction among Adolescents
}

\author{
Mohd. Ahamar Khan 1
}

\begin{abstract}
ABATRACT
The aim of this study was to find out the relationship between social support and life satisfaction among adolescents. The sample consisted of $\mathrm{N}=80$ participants. Multidimensional Scale of Perceived Social Support (MSPSS) developed by Zimet et al. (1988) and Satisfaction with Life Scale (SWLF) prepared by Diener et al. (1985), were used to collect the data. The Simple Linear Regression and Pearson Correlation were used for data analyses. The findings of this study revealed that, there is positive and significant relationship between social support and life satisfaction of adolescents. Further this study indicates that social support influences life satisfaction of adolescents. This study may have its own significance in managing psychological distress and optimizing life satisfaction to adolescents at large.
\end{abstract}

Keywords: Social Support, Life Satisfaction and Adolescents.

\section{INTRODUCTION:}

\section{Social Support}

The concept of social support has been widely used by the investigators such as social bonds (Henderson, 1977), social networks (Mueller, 1980), meaningful social contact (Cassel, 1976), availability of social confidents (Brown et al., 1975), and human companionship (Lynch, 1977). Cobb (1976) defined social support as, "Information leading the subject to believe that he is cared for and loved, esteemed and a member of a network of mutual obligations." Cohen and Syme (1985) conceptualised social support as the existence of people on whom we can rely, people let us know that they care about, value, and love us. House (1981) defined social support "as an interpersonal transaction" involving one or more of the following features:

(I) Emotional concern (liking, love and empathy).

(II) Instrumental aid (goods or services).

(III) Information (about the environment).

(IV) Appraisal (information relevant to self-evaluation).

Social support develops strong interpersonal relationship among the people, which play significant role in practical life. Shumaker and Brownell (1984) argued that supportive behaviour as "an exchange of resources between two individuals perceived by the provider or the recipient to the intended to enhance the well-being of recipient." These attractions tend to be viewed as supportive when they are intended to gratify people's need (Thoits, 1982).

${ }^{1}$ Research Scholar, Department of Psychology, Aligarh Muslim University, Aligarh

(C) 2015, A Khan; licensee IJIP. This is an Open Access Research distributed under the terms of the Creative Commons Attribution License (http://creativecommons.org/licenses/by/2.0), which permits unrestricted use, distribution, and reproduction in any Medium, provided the original work is properly cited. 
Impact of Social Support on Life Satisfaction among Adolescents

\section{Forms of Social Support}

Researchers identified various forms of social support in relation to different context. Because of people require specific type of support in specific situation. The major categories of social support proposed by the investigators as: informational, tangible, emotional, esteem, appraisal, instrumental and social network support (Schaefer, Coyne, and Lazarus, 1981; Weiss, 1974).

\section{Sources of Social Support}

Social support constitutes from a variety of sources, including: family, friends, romantic partners, pets, community ties, and co-workers (Taylor, 2011). It can be natural or more formal (Hogan, Linden, and Najarain, 2002). The source of the social support is a significant determinant of its effectiveness as a coping strategy. Support from a romantic partner is related with health benefits, especially for men (Kiecolt-Glaser, Newton, 2001). Jackson conducted one study and found that support from spouses buffered the negative effects of work stress; it did not buffer the association between marital and parental stresses, because the spouses were implicated in these situations. Additionally, he found that social support from friends did provide a buffer in response to marital stress, because they were less implicated in the marital dynamic. Repetti, Taylor, and Seeman (2002) found that early familial social support showed important for children's abilities to develop social competencies and supportive parental relationships with children have also had benefits for college-aged students (Valentiner, Holohan,and Moos 1994). Researchers suggest that social support positively predictor to psychological well-being, eventual completion of formal education, work-career achievement, and marital stability (Furstenberg and Crawford, 1978; Garbarino, 1982; Wandersman and Wandersman, 1980; Zuckerman, Winsmore, and Alpert, 1979).

\section{Life Satisfaction}

According to Webster's dictionary (1996) satisfaction with one's life refers to acceptance of life circumstances and the fulfilment of wants and needs for life as a whole. Diener et al. (1999) defined life satisfaction as a desire to change one's life, satisfaction with past, satisfaction with future, and significant views of one's life. Sumner (1996) argued life satisfaction as "A positive evaluation of the conditions of your life, a judgment that, at least on balance, it measures up favourably against your standards or expectations".

Neugarten et al (1961) proposed two approaches of life satisfaction. One refers to the overt behaviour using social criteria of success, or competence, and second is an individual's own interpretation and evaluation of his/her present and past life. Life satisfaction also refers to the attitudes that individuals have about their past, present as well as future in relation to their psychological well-being (Chadha \&Willigen, 1995). Shin and Johanson (1978) suggested life satisfaction as "a global assessment of a person's quality of life according to him chosen criteria".

\section{LITERATURE REVIEW}

Wenk et al. (1994) in their study found that the both girls and boys feeling about close to their father had a significant positive effect on life satisfaction. Grossman and Rowat (1995) conducted study among a group of Canadian adolescents and found that perceived poor parental relationship, and not family status, was related with least life satisfaction. This finding also supported by similar study which conducted by Heaven et al. (1996) among Australian 
adolescents, where perceived family functioning was found to be positively related with life satisfaction, self-esteem, and extraversion, and negatively related with neuroticism and psychoticism.

Baker et al. (1992) conducted study among 844 people with chronic psychiatric illness receiving community support services, case management service, as one type of social support, and reported the improvement of participant's subjective overall life satisfaction over the nine months period. Therefore, the increase of social support was related to the increase of subjective overall life satisfaction.

Earls and Nelson (1988) reported that frequency of actual social support was related with people's life satisfaction for psychiatric illness. On the other hand similar result was found by Turner and Noh (1983) whereas perceived social support was correlated with psychological wellbeing among the people with psychotic mental illness.

In the light of past research, it is found that social support and life satisfaction are highly related to each other. Social support showed practical as well as clinical significance to enhance overall well-being and to manage psychological as well as physical disturbances. Although, it is very important to mention that life satisfaction with the consideration of social support among adolescents have been widely studied in the western countries but have lack of research in Indian context among the adolescents. Because of Indian living discipline are quite different from west. This real fact made the attention of investigator towards the present research investigation.

\section{OBJECTIVES OF THE STUDY}

The main objectives of the present research are as follows:

1. To determine the relationship between social support and life satisfaction among adolescents.

2. To determine the influence of social support on life satisfaction among adolescents.

\section{HYPOTHESES OF THE STUDY}

In the light of relevant literature the following hypotheses were formulated:

H-(1) There will be significant positive relationship between social support and life satisfaction among adolescents.

H-(2) There will be significant influence of social support on life satisfaction among adolescents.

\section{SAMPLE OF THE STUDY}

In the present investigation a sample of 80 male students (age 18 to 25) were selected by simple random sampling techniques from Aligarh Muslim University, Aligarh.

\section{TOOLS USED}

The two different scales namely; Multidimensional Scale of Perceived Social Support and Satisfaction with Life Scale, were used for data collection. The brief description of the scales used in the present study is presented in the following manner. 


\section{Multidimensional Scale of Perceived Social Support}

This scale was developed by Zimet, Dahlam, Zimet and Farley (1988). This scale consisted of 12 items. Minimum and maximum score ranges between 7 to 84 .The internal consistency and testretest reliability of this scale were found to be 0.88 and 0.85 respectively. The validity of this scale also found to be quite satisfactory.

\section{Satisfaction with Life Scale}

This scale was developed by Diener, Emmons, Larsen, and Griffin (1985). This scale consisted of 5 items. Minimum and maximum score ranges between7 to 35 . Higher score indicates more satisfaction. The test-retest reliability was found to be 0.82 . The Cronbach's alpha was found to be 0.87 .

\section{PROCEDURE OF DATA COLLECTION}

Good rapport was established with participants before requesting to fill up the questionnaire and then instructions were invariably explained to the participants. After that questionnaires were distributed individually. Subjects were assured of confidentiality of their responses and were requested to extend their co-operation. Finally questionnaires were collected from all the participants, scoring done and analyses were carried on.

\section{STATISTICAL ANALYSES AND RESULTS}

Table-1: Represents Pearson Correlation between Social Support and Life Satisfaction among Adolescents.

\section{Correlations}

\begin{tabular}{|ll|r|r|}
\hline & \multicolumn{1}{|c|}{$\begin{array}{c}\text { Social } \\
\text { Support }\end{array}$} & \multicolumn{1}{c|}{$\begin{array}{c}\text { Life } \\
\text { Satisfaction }\end{array}$} \\
\hline Social Support & Pearson & 1 & $.454^{* *}$ \\
& Correlation & & \\
& Sig. (2-tailed) & & .000 \\
& $\mathrm{~N}$ & 80 & 80 \\
\hline Life & Pearson & $.454^{* * *}$ & 1 \\
Satisfaction & Correlation & & 80 \\
& Sig. (2-tailed) & .000 & \\
& $\mathrm{~N}$ & 80 & \\
\hline
\end{tabular}

**. Correlation is significant at the 0.01 level (2-tailed).

The above table indicates that social support positively correlated with Life Satisfaction (.454) at the 0.01 level of significance (2-tailed). Thus, the first underlined hypothesis of the present investigation that ("there will be significant positive relationship between social support and life satisfaction among adolescents"') is proved. 
Table-2: Represents Simple Linear Regression analysis, Social Support as predictor of Life Satisfaction among Adolescents.

Model Summary

\begin{tabular}{|l|l|r|c|c|}
\hline Model & \multicolumn{1}{|c|}{$\mathrm{R}$} & R Square & \multicolumn{1}{c|}{$\begin{array}{c}\text { Adjusted R } \\
\text { Square }\end{array}$} & $\begin{array}{c}\text { R Square } \\
\text { Change }\end{array}$ \\
\hline 1 & $.454^{\mathrm{a}}$ & .206 & .196 & .206 \\
\hline
\end{tabular}

a. Predictor: (Constant), Social Support

The above table shows the model summary indicating one predictor (social support) of the model, in which correlation between social support and life satisfaction was found to be $\mathrm{R}=.454$. Further R square change was found to be .206 which represents the $20.6 \%$ actual contribution of predictor variable (social support) to criterion variable (life satisfaction).

Table-3: Showing the Coefficient details of Social Support and Life Satisfaction among Adolescents

\section{Coefficientsa}

\begin{tabular}{|c|c|c|c|c|c|c|}
\hline \multirow{2}{*}{\multicolumn{2}{|c|}{ Model }} & \multicolumn{2}{|c|}{$\begin{array}{l}\text { Unstandardized } \\
\text { Coefficients }\end{array}$} & $\begin{array}{l}\text { Standardized } \\
\text { Coefficients }\end{array}$ & \multirow[b]{2}{*}{$\mathrm{t}$} & \multirow[b]{2}{*}{ Sig. } \\
\hline & & B & Std. Error & Beta & & \\
\hline 1 & (Constant) & 11.526 & 2.437 & & 4.731 & .000 \\
\hline & $\begin{array}{l}\text { Social } \\
\text { Support }\end{array}$ & .180 & .040 & .454 & 4.501 & .000 \\
\hline
\end{tabular}

a. Dependent Variable: Life Satisfaction

The above table indicates that the value of $\beta=.454$ shows the social support positively related with life satisfaction of adolescents. The t-value found to be 4.501 , which was significant at 0.01level for social support. Thus, the second underlined hypothesis of the present investigation that ("there will be significant influence of social support on life satisfaction among adolescents") is proved.

\section{DISCUSSION}

The above obtained findings clearly indicate that social support positively related with life satisfaction. It also shows that social-support emerge as a predictor of life satisfaction. These 
findings supported by various research findings such as; Baker et al. (1992) conducted study among 844 people with chronic psychiatric illness receiving community support services, case management service, as one type of social support, and reported the improvement of participant's subjective overall life satisfaction over the nine months period. Therefore, the increase of social support was related to the increase of subjective overall life satisfaction. Further, Earls and Nelson (1988) in their study also found that frequency of actual social support was related with people's life satisfaction for psychiatric illness. Thus, social support has good significance in practical life; it could serve as a guide to enhance adolescent's overall life satisfaction and remove mental, emotional, behavioral, and physical distress.

\section{LIMITATIONS OF THE STUDY}

It is universally accepted that every research study have its own limitations especially for social sciences research. It could not possible for any researcher to cover whole area of a particular research in one study. Research process is also learning process for researcher in which, researchers clarify their concepts and improve methodological issues for further research study in future. Thus, like other research study the present study also have its own limitations. The size of the sample of this study is limited, which develops limitation towards the generalization of findings of the present investigation. This research study was conducted on only male adolescents, and neglected female adolescents for participation in this investigation. The present investigation confined with only adolescents age group, not to whole of male as well as female age group. This limitation of the present investigation again brings limitations on the generalizations of the present findings.

\section{REFERENCES}

1. Author : Mohd Ahamar Khan, Research Scholar, Aligarh Muslim University, Aligarh, India.

2. Baker F., Jodrey D., J.Intagliata (1992) Social support and quality of life of community support clients Community Mental Health Journal 28:397-411.

3. Brown, G. W., Bhrolchain, M. N., \& Harris, T. (1975). Social class and psychiatric disturbance among women in an urban population. Sociology, 9, 225-54.

4. Cassel, J. (1976). The contribution of social environment to host resistance. American Journal of Epidemiology, 104, 107-123.

5. Chadha, N. K., \& Willigen, J. V. (1995). The Life scale: The development of a measure of successful aging. Indian Journal of Gerontology, 9(3 \& 4), 83-90.

6. Cobb, S. (1976). Social support and health through the life course. In Burleson, B.R., Albrecht, T.I. \& Sarason, I.G. (eds.). Communication of Social Support: Massages, Relation and Community. Thousand Oaks: CA: Sage Pp. 116.

7. Cobb, S. (1976). Social support as a moderator of life stress. Psychomatic Medicine, 38, 300-314.

8. Cohen, S., \& Syme, S.L. (1985). Stress, social support and the buffering hypothesis. Psychological Bulletin, 88, 310-357. 
9. Diener, E., Emmons, R., Larsen, R. J., Griffin, S. (1985). The satisfaction with life scale. Journal of Personality Assessment, 49, 71-75.

10. Diener, E., Suh, E. M., Lucas, R., \& Smith, H. L. (1999). Subjective well-being: Three decades of progress. Psychological Bulletin, 125, 276-302. .

11. Earls M., Nelson G. (1988) The relationship between long term psychiatric clients' psychological well being and their perceptions of housing and social support American Journal of Community Psychology 16:279-293

12. Furstenberg, F., \& Crawford, A. G. (1978). Family support: Helping teenage mothers to cope. Family Planning Perspectives, 10, 322-333.

13. Garbarino, J. (1982). Children and families in the social environment. New York: Aldine.

14. Grossman, M., \& Rowat, K. M. (1995). Parental relationships, coping strategies, received support and well- being in adolescents of separated or divorced and married parents. Research in Nursing \& Health, 18, 249-261.

15. Heaven, P., Searight, H. R., Chastain, J., \& Skitka, L. J. (1996). The relationship between perceived family health and personality functioning among Australian adolescents. American Journal of Family Therapy, 24, 358-366.

16. Henderson, S. (1977). The social network, support and neurosis: The function of attachment in adult life. British Journal of Psychiatry, 131, 391-398.

17. Hogan, B.; Linden, W.; Najarian, B. (2002). "Social support interventions: Do they work?" Clinical Psychology Review 22 (3): 381-440.

18. House, J. S. (1981). Work Stress and Social Support. Reading. MA: Addison-Wesley

19. Jackson, P. B. "Specifying the buffering hypothesis: Support, strain, and depression". Social Psychology Quarterly55: 363-378.

20. Kiecolt-Glaser, J.K.; Newton, T.L. (2001). "Marriage and health: His and hers". Psychological Bulletin 127(4): 472-503.

21. Lynch, J. (1977). The broken heart. New York: Basic.

22. Mueller, D. P. (1980). Social Networks: A promising direction for the research on the relationship of the social environment to psychiatric disorder. Social Science and Medicine, 14, 147-161.

23. Neugarten, B. L., Havighurst, R. J., \& Tobin, S. S. (1961). The measurement of life satisfaction. Journal of Gerontology, 16, 134- 143.

24. Repetti, R.L.; Taylor, S.E.; Seeman, T.E. (2002). "Risky families: Family social environments and the mental and physical health of offspring". Psychological Bulletin 128 (2): 330-336.

25. Schaefer, C., Coyne, J.C., \& Lazarus, R.S. (1981). The health-related function of social support. Journal of Behavioural Medicine, 4, 381-406.

26. Shin, D. C., \& Johnson, D. M. (1978). A viewed happiness as an overall assessment on quality of life. Social Indicators Research, 5, 475-492.

27. Shumaker, S.S., \& Brownell, A. (1984). Towards a theory of social support closing conceptual gaps. Journal of Social Issues, 46, 11-36.

28. Sumner, L. W. (1996). Welfare, happiness, and ethics. New York: Oxford University Press.

29. Taylor, S.E. (2011). "Social support: A Review". In M.S. Friedman. The Handbook of Health Psychology. New York,NY: Oxford University Press. pp. 189-214

30. Thoits, P. A. (1982). Conceptual, methodological and theoretical problems in studying social support as a buffer against life stress. Journal of Health and Social Behavior, 23, 145- 159. . 
31. Turner R.J., Noh S. (1983) Class and psychological vulnerability among women: the significance of social support and personal control Journal of Health and Social Behaviour 24:2-15

32. Valentiner, D.P.; Holahan, C.J,, Moos, R.H. (1994). "Social support, appraisals of event controllability, and coping: An integrative model". Journal of Personality and Social Psychology 66: 1094-1102.

33. Wandersman, L., \& Wandersman, A. (1980). Social support in the transition to parenthood. Journal of Community Psychology, 8, 332-342.

34. Webster's encyclopaedic unabridged dictionary of the English language (1996). Gramercy Books, New York.

35. Weiss, R.S. (1974). The provisions of social relationships. In Burleson, B. R., Albrecht, T. I. \& Sarason, I. G. (eds.). Communication of Social Support: Massages, Relationships and Community. Thousand Oaks: Ca: Sage.

36. Wenk, D. A., Hardesty, C. L., Morgan, C. S., \& Blair, S. L. (1994). The influence of parental involvement on the well-being of sons and daughters. Journal of Marriage \& the Family, 56, 229-234.

37. Zimet, G. D., Dahlem, N. W., Zimet, S. G., \& Farley, G. K. (1988). The multidimensional scale of perceived social support. Journal of Personality Assessment, $52,30-41$.

38. Zuckerman, B., Winsomore, G., \& Alpert, J. J. (1979). A study of attitudes and support systems in inner-city adolescent mothers. Journal of Pediatrics, 95, 122-125.. 